Creative Commons User License: CC BY-NC-ND

Abstracted by: EBSCOhost, Electronic Journals Service (EJS), Google Scholar, Journal Seek, Scientific Commons,

Food and Agricultural Organization (FAO), CABI and Scopus

http://eoi.citefactor.org/10.11226/v24i3
Journal of Agricultural Extension

Vol. 24 (3) July, 2020

ISSN(e): 24086851; ISSN(Print); 1119944X

http://journal.aesonnigeria.org

http://www.ajol.info/index.php/jae

Email: editorinchief@aesonnigeria.org

\title{
Division of Labour in Rice Production and Processing across Gender in Ogun State, Nigeria \\ https://dx.doi.org/10.4314/jae.v24i3.6
}

\author{
Akinnagbe, Oluwole Matthew \\ Department of Agricultural Extension \& Communication Technology, \\ Federal University of Technology, Akure, Ondo State, Nigeria. \\ Email:omakinnagbe@futa.edu.ng; wolexakins@yahoo.com \\ Phone: +2348035399151
}

\section{Ayibiowu, Oluwatoyin Oyekanmi}

Department of Agricultural Extension \& Communication Technology,

Federal University of Technology, Akure, Ondo State, Nigeria.

Email:ooayibiowu@gmail.com

Phone: +2347032244532

\section{Abstract}

This study assessed division of labour in rice production and processing across gender in Ogun state, Nigeria. Multistage sampling procedure was used in sampling 120 rice farmers who are both producers and processors. Primary data were obtained from the respondents with the use of structured interview schedule. Data were analysed using frequency, percentage, charts, mean and t-test statistic. The findings revealed that, in rice production; clearing of farm land (90.0\%), de-stumping/packing (98.3\%), and tilling of land (98.3\%) were mainly carried out by men while women were more involved in activities such as planting (52.5\%), weeding (50.8\%), bird scaring (69.\%), harvesting and packing (74.2\%). In rice processing; men performed major activities in milling (95.8\%), de-stoning (95.0\%) and transportation (91.6\%) while women were more involved in threshing (84.2\%), sun drying (80.9\%), and winnowing (87.5\%). The result of $t$ test showed that, there was significant differences in the average quantity of rice $(\mathrm{kg})$ produced by men and women in year 2012 $(t=3.930 ; p \leq 0.05), 2013$ ( $t=4.748 ; p \leq 0.05), 2014$ ( $t=3.570 ; p \leq 0.05)$ and 2016 ( $t=3.096) ; p \leq 0.05)$ but there was no significant difference between the average rice produced by men and women ( $t=0.308 ; p>0.05)$ in year 2015. Interventions to address the rice production and processing in major energy require activities (like clearing, milling) should be tailored towards men while low energy activities (like planting, harvesting, marketing) interventions should be tailored towards women in order to enhance high productivity and quality processing.

Keywords: gender division of labour, rice production, rice processing 
Creative Commons User License: CC BY-NC-ND

Abstracted by: EBSCOhost, Electronic Journals Service (EJS), Google Scholar, Journal Seek, Scientific Commons,

Food and Agricultural Organization (FAO), CABI and Scopus
Journal of Agricultural Extension

Vol. 24 (3) July, 2020

ISSN(e): 24086851; ISSN(Print); 1119944X

http://journal.aesonnigeria.org

http://www.ajol.info/index.php/jae

Email: editorinchief@aesonnigeria.org

\section{Introduction}

Globally, rice is a staple food to over $50 \%$ of people and the most important among all the cereal crops. It is mainly cultivated by small farmers (Ojo, Ogundeji, Babu and Alimi, 2020; Edeoghon, lyilade and Nwachukwu, 2019; Okunola, Bamigboye, Olayanju, Osueke and Alhassan, 2018). Over 3.5 billion individuals depend on rice for more than $20 \%$ of their daily calories with Asia, South America and sub-Saharan Africa as the largest consuming regions. Rice provides up to $50 \%$ of the dietary caloric supply for hundreds of millions in Asia and is, therefore, critical for food security. In Sub-Saharan Africa, rice is the fastest growing staple food, with annual per capita consumption of $27 \mathrm{~kg} / \mathrm{year}$ (KPMG international, 2019). Approximately 480 million metric tons of milled rice is produced annually. China and India alone account for $50 \%$ of the rice grown and consumed (Mohammed, Ibrahim, Hayatu and Mohammed, 2019). In Nigeria, rice is one of the few food items whose consumption has no cultural, religious, ethnic or geographical boundary (Salami, Babatunde, Ayinde and Adeoti, 2017). However, the global demand for rice is continually increasing (Mohd Hanafiah, Mispan, Lim, Baisakh, and Cheng, 2020). It is consumed across all geo-political zones and socioeconomic classes in Nigeria. Only about $57 \%$ of the 6.7 million metric tonnes of rice consumed in Nigeria annually, is locally produced (KPMG international, 2019).

Rice is planted April-May in the south and harvested in August-September. The production season extends to June-July in the north with a November-December harvest. There is a second off-reason production in the south in the NovemberDecember time-period, with a harvest in March-April. In the north, the off-season production runs from January-February with a May-June harvest. Rice cultivated in Nigeria includes Fadama rice (irrigated, flooded field, Oryza sativa), Ofada (heritage varieties grown in southwest Nigeria), FARO 44 (a semi-dwarf cultivar), and upland and lowland rice types. Local rice varieties (i.e., short-grain heritage types) are a traditional staple food consumed within the rice-producing communities (Global Africa Information Network, 2019).

Nigeria is the largest producer of rice in West Africa (second in Africa, after Egypt). The average yield in the country is approximately 1.8 metric tonnes per hectare. Over $70 \%$ of rice production in Nigeria is from rain fed lowlands and irrigated land systems. (KPMG international, 2019). Rice is the third-most consumed staple food in Nigeria (after maize and cassava) and has become a food security crop due to its increased significance. Rice is cultivated in all Nigeria's agro-ecological zones. Almost all states in Nigeria produce rice. However, the North-Western region of the country produces the highest volumes, followed by the North Central region. Ebonyi, Ogun and Ekiti states produce of the most rice in the southern region. Most farmers and processors still practice the local or traditional methods in rice processing. Harvesting is done when $80 \%$ of the grain has turned to straw colour. Rice processing requires special skills since large percentages of broken rice are not desirable in commercial packages (Okunola, Adekanye, Adewumi, and Ashamu, 2019). As noted by Lusiba, Kibwika and Kyazze (2017), rice postharvest handling 
Creative Commons User License: CC BY-NC-ND

Abstracted by: EBSCOhost, Electronic Journals Service (EJS), Google Scholar, Journal Seek, Scientific Commons,

Food and Agricultural Organization (FAO), CABI and Scopus

http://eoi.citefactor.org/10.11226/v24i3
Journal of Agricultural Extension

Vol. 24 (3) July, 2020

ISSN(e): 24086851; ISSN(Print); 1119944X

http://journal.aesonnigeria.org

http://www.ajol.info/index.php/jae

Email: editorinchief@aesonnigeria.org

activities are manual, labour intensive, tedious, slow and time consuming compared to other crops such as maize.

The gender participation in rice cultivation is clearly seen in the different stages of production from land clearing, tilling, weeding, planting, harvesting, transplanting, drying, cleaning, threshing, winnowing, packaging, storage, transportation. These operations are commonly dominated by a particular gender group due to some certain factors like laborious nature of the work, tradition or custom and lots more (Edeoghon, et., 2019). According to Subramanian (2018), the role of women in public life and in the social context has changed in the last few decades. On gender under-representation in agricultural production and productivity, (African Development Bank (AfDB), 2016) affirmed that the diversity of the African continent prompted the diverse roles ascribed to the male and female gender. Gender here refers to a social and cultural construct, which distinguishes differences in the attributes of men and women, girls and boys, and accordingly refers to the roles and responsibilities of men and women. Gender-based roles and other attributes, therefore, change over time and vary with different cultural contexts (United Nations Children Emergency Funds (UNICEF), 2017).

Rice being an important component of Nigerian diet, and in view of the current ban on importation of rice into the country by the Federal Government of Nigeria, has led to considerable interest in increasing the local production and processing. It is therefore important to ascertain individual roles in rice production and processing across gender.

The study assessed the division of labour in rice production and processing across gender in Ogun state, Nigeria. Specifically, the study; identified the varieties of rice grown; ascertain the sources of information; determined the roles performed by men and women in rice production and processing; and determine rice output based on gender from year 2012 to 2016.

\section{Methodology}

The study was carried out in Ogun state, situated between latitude $6.2^{\circ} \mathrm{N}$ and $7.8^{\circ} \mathrm{N}$ and longitude $3.0^{\circ} \mathrm{E}$ and $5.0^{\circ} \mathrm{E}$., with a total landmass of about $16,409.26$ square kilometres. The estimated projected population of the state in 2016 is 5,217,716 persons made up of 2,661,035 males and 2,556,681 females (National Population Commission, 2016).

The population of the study comprised of all the rice farmers who are involved in both production and processing in Ogun state. A multistage sampling procedure was used to select the respondents. According to Osabuohien, Okorie and Osabohien (2018), eight out of the twenty local government areas (LGAs) in Ogun state, are major LGAs involved in rice production in the state. These LGAs are: Abeokuta North, Yewa north (formerly Egbado north), Ewekoro, Ifo, ljebu-North, Ikenne, Obafemi Owode, and Ogun Waterside. The first stage involved random selection of 
Creative Commons User License: CC BY-NC-ND

Abstracted by: EBSCOhost, Electronic Journals Service (EJS), Google Scholar, Journal Seek, Scientific Commons,

Food and Agricultural Organization (FAO), CABI and Scopus
Journal of Agricultural Extension

Vol. 24 (3) July, 2020

ISSN(e): 24086851; ISSN(Print); 1119944X

http://journal.aesonnigeria.org

http://www.ajol.info/index.php/iae

Email: editorinchief@aesonnigeria.org

three out of eight LGAs involved in rice production in the state. These LGAs are; Yewa north, Obafemi Owode and Ogun Waterside.

In the second stage, two village communities were purposively selected from each of the three LGAs selected because of the rice production output, giving a total of six villages. In the third stage that involved selection of respondents, a list of registered rice producers and processors was collected from the rice farmers' cooperatives available in the village communities. From the list of 25-30 members, twenty rice farmers (ten men and ten women) who are involved in both rice production and processing, were purposefully selected from each of the village communities, so that they would be able to provide information for both production and processing. Making a total of forty rice farmers (twenty men and twenty women) per LGAs. In all, a total of one hundred and twenty respondents (sixty men and sixty women) constituted the sample size for the study.

Primary data were collected from the respondents through the use of a structured interview schedule. The instrument for data collection was validated by experts in the field of agricultural extension and rural development. To determine division of labour in rice production and processing across gender, various rice production and processing were listed for the respondents to ascertain who perform each of the activities. To determine the changes on rice output from year 2012 to 2016, respondents were asked to indicate their yearly output (rice) in kilogram (kg), the mean of production for each year was calculated and then compared. This information on rice output was gotten through memory recall and was considered as valid, since majority of the farmers were not used to keeping records of farm events. Memory recall data, collected as satisfactory as possible, are valid for use in social research. Data were analysed using frequency, percentage, and mean and t-test statistics. The IBM-SPSS Statistics was used for the data analysis.

\section{Results and Discussion}

\section{Rice Production System and Varieties of Rice Grown}

The result in Figure 1 shows that $70.0 \%$ of the men and $76.7 \%$ of the women planted upland rice, $16.6 \%$ of the men and $16.6 \%$ of the women planted lowland rice while $13.4 \%$ of the men and $6.7 \%$ of the women planted both upland and lowland rice. This implies that upland rice was planted by the respondents. This is in support of the finding of Omoare and Oyediran (2020) that more than ninety percent of the respondents practiced lowland rice farming system in Ogun and Niger states. Monica, Kwasi and Ernestina (2016) finding revealed that high percentage of male was recorded in upland rice production with low number of female rice farmers involved in upland rice production in Sub-Saharan Africa.

On varieties of rice grown, $31.6 \%$ of the men and $38.4 \%$ of the women grew Faro 44 , while $28.4 \%$ of the men and $36.6 \%$ of the women grew Ofada. About $30 \%$ of the men and $18 \%$ of the women grew Faro 52 , while $1.7 \%$ of both men and women grew NERICA 8 and Faro 17, respectively. This implies that different varieties of rice were 
Creative Commons User License: CC BY-NC-ND

Abstracted by: EBSCOhost, Electronic Journals Service (EJS), Google Scholar, Journal Seek, Scientific Commons,

Food and Agricultural Organization (FAO), CABI and Scopus

http://eoi.citefactor.org/10.11226/v24i3
Journal of Agricultural Extension

Vol. 24 (3) July, 2020

ISSN(e): 24086851; ISSN(Print); 1119944X

http://journal.aesonnigeria.org

http://www.ajol.info/index.php/jae

Email: editorinchief@aesonnigeria.org

grown in the study area due to the importance of each and nutritious value as opined by Osuoha, (2014), but the majority of the respondents cultivated Faro 14. This is attributed to its short period of maturity and high yield. Although Ofada rice has high demand by consumers due to its taste and aroma, growing of other varieties could be attributed to the support given by different bodies in increasing rice production and processing in Ogun state.

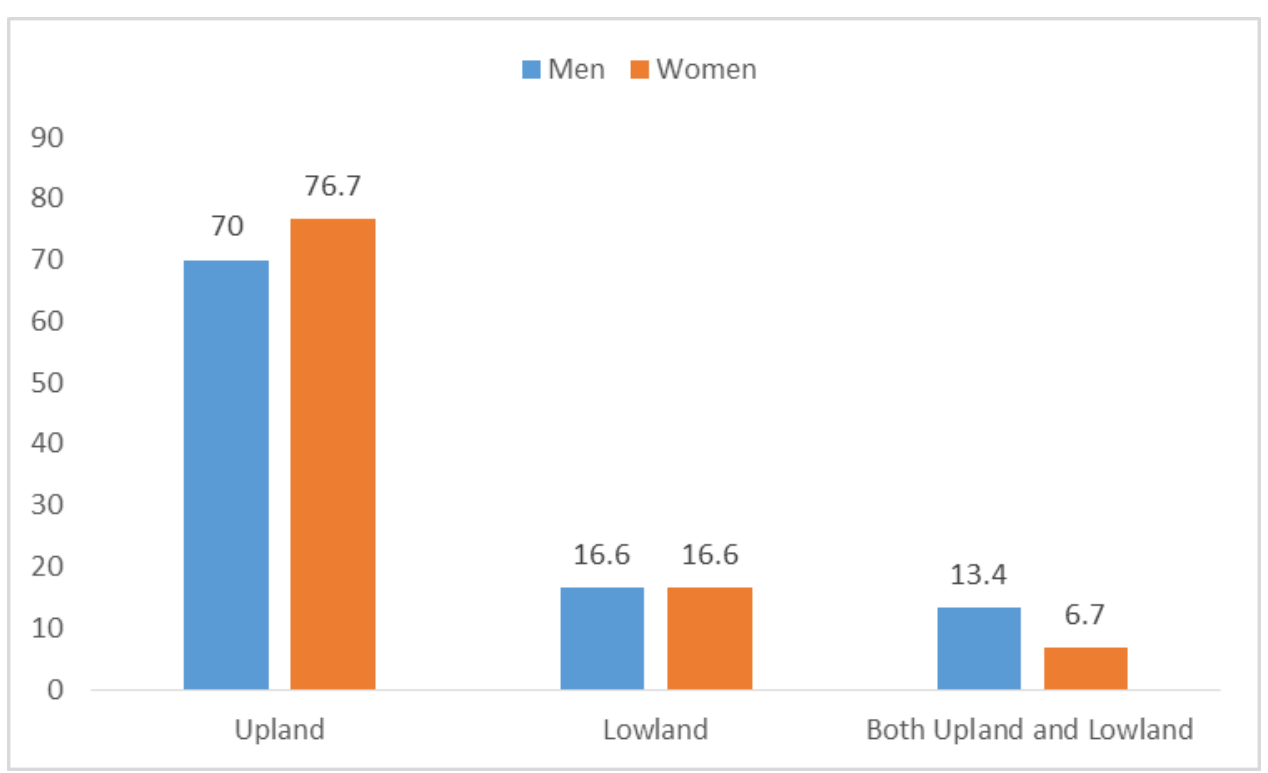

Figure 1: Rice production system

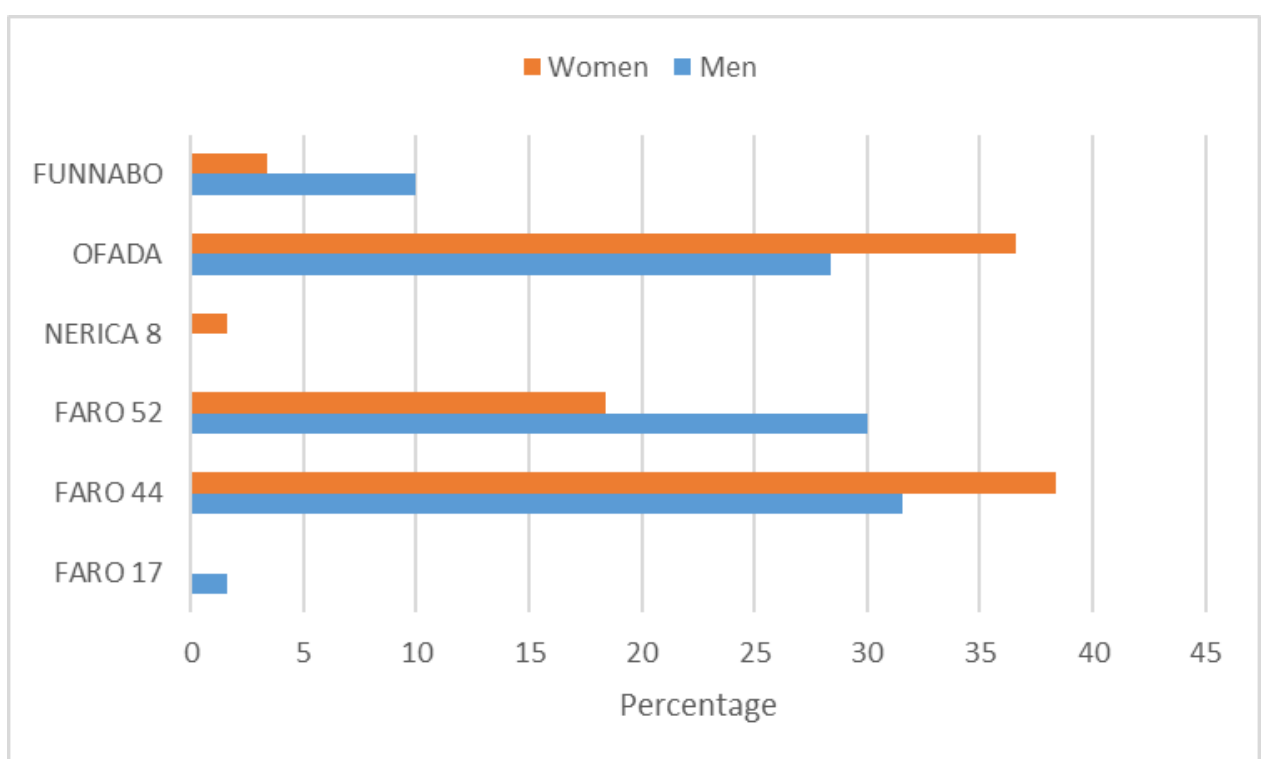

Figure 2: Varieties of rice planted

Sources of Information on Rice Production and Processing

Table 1 shows that $35.0 \%$ of the men and $40.0 \%$ of the women got their information through Fadama staff, $26.7 \%$ of the men and $18.3 \%$ of the women indicated radio as 
Creative Commons User License: CC BY-NC-ND

Abstracted by: EBSCOhost, Electronic Journals Service (EJS), Google Scholar, Journal Seek, Scientific Commons,

Food and Agricultural Organization (FAO), CABI and Scopus
Journal of Agricultural Extension

Vol. 24 (3) July, 2020

ISSN(e): 24086851; ISSN(Print); 1119944X

http://journal.aesonnigeria.org

http://www.ajol.info/index.php/jae

Email: editorinchief@aesonnigeria.org

their source of information, $13.3 \%$ of the men and $18.3 \%$ of the women indicated cooperative societies, $8.3 \%$ of the men and $3.3 \%$ of the women had extension agent from ADP as their source of information while $1.7 \%$ of the men and $3.3 \%$ of the women indicated friends and neighbours as their source of information. This shows high functionality of Fadama staff as sources of information on rice production and processing. This could be attributed to the role of Fadama in increasing food production in Nigeria as the staff took information dissemination on rice production and processing as one of their major task due to the importance of rice as staple food crop in Nigeria.

Table 1: Sources of information on rice production and processing

\begin{tabular}{lcc}
\hline & Male & Female \\
\cline { 2 - 3 } Information sources & $\%$ & $\%$ \\
\hline Fellow farmers & 6.7 & 8.3 \\
Friends and neighbour & 1.7 & 3.3 \\
Cooperative Societies & 13.3 & 18.3 \\
Television & 8.3 & 8.3 \\
Extension Agent from ADP & 8.3 & 3.3 \\
Radio & 26.7 & 18.3 \\
Fadama staff & 35.0 & 40.0 \\
\hline
\end{tabular}

\section{Division of Labour in Rice Production and Processing across Gender}

Table 2 shows division of labour in rice production and processing across gender. The result revealed that men were more involved in the following rice production activities; clearing of land (90.0\%), de-stumping of farmland (98.3\%), tilling of land $(98.3 \%)$ and application of fertilizer $(90.0 \%)$. Women were more involved in the following rice production activities; planting (52.5\%), weeding (50.8\%), thinning $(50.8 \%)$, bird scaring $(69.1 \%)$, harvesting $(74.2 \%)$ and heaping/packing of harvested rice $(79.2 \%)$. Children gave reasonable assistance to both men and women in the following activities; clearing of land (10.0\%), bird scaring (21.7\%); with $5.8 \%$ each in harvesting and packing of harvested rice. This implies that, men performed major role in physical activities like land clearing and tilling, while women major roles were in planting, harvesting, transportation of harvested rice from farms to their homes and marketing could be termed low energy required activities.

This result supports the findings of Iwuchukwu \& Udegbunam (2017) that men were more involved in clearing of rice farmland and application of fertilizer, while women were more involved in planting and weeding. It is also in agreement with Addison, Ohene-Yankyera, Fredua-Antoh (2016) that the more strenuous activities such as land preparation, are mostly carried out by male rice farmers in Ahafo Ano North District in Ashanti Region of Ghana, while females are more dedicated in activities such as planting, weeding, heaping/packaging of harvested rice. 
Creative Commons User License: CC BY-NC-ND

Abstracted by: EBSCOhost, Electronic Journals Service (EJS), Google Scholar, Journal Seek, Scientific Commons,

Food and Agricultural Organization (FAO), CABI and Scopus
Journal of Agricultural Extension

Vol. 24 (3) July, 2020

ISSN(e): 24086851; ISSN(Print); 1119944X

http://journal.aesonnigeria.org

http://www.ajol.info/index.php/jae

Email: editorinchief@aesonnigeria.org

The processing activities in rice start from the time of harvesting up to storage and marketing. Each of these stages involves several activities. The result revealed that men were more involved in the following rice processing activities like milling $(95.8 \%)$, de-stoning $(95.8 \%)$ and transporting $(91.6 \%)$, while women were more involved in; threshing $(84.2 \%)$, sun drying $(80.9 \%)$, bagging $(75.8 \%)$, soaking $(91.7 \%)$, winnowing $(87.5 \%)$, parboiling $(75.0 \%)$, sun drying after parboiling $(73.3 \%)$, bagging $(75.0 \%)$, packaging $(84.2 \%)$ storing $(80.0 \%)$ and marketing $(90.0 \%)$. Although children help in performing moderate roles in some of these activities.

Harvesting starts once maturity of the crop is established. After this, heaping is the next stage. Heaping is the collecting and hauling of the cut rice and piling it where it is threshed. The heaping sites are carefully selected within the rice field and are usually on raised ground and must not be waterlogged or muddy. The rice once heaped can stay for some days before threshing. These two activities were dominated by women. Threshing is done using motorized and pedal threshers alongside the manual. Threshing required a lot of physical energy, skill and experience to ensure that all grains are removed from the panicles with minimal spillage. The dominance of women in the use of technologies such as the motorized and pedal threshers may demonstrate appropriate targeting of technologies and innovation. It is also sensitivity of the technologies and innovation on gender basis. In transporting the threshed rice from the field to home, the men accounted for $91.6 \%$ of the work compared to $4.2 \%$ for women.

After threshing, the next activities are drying, winnowing and storage. There is a marked change in division of labour patterns as one moves from the field-based to home-based processes of drying and winnowing. Drying involves two main tasks; putting out the rice in the sun to dry and taking it out of the sun, and regularly turning the rice to ensure uniform drying. Women performed the task (73.3\%). Children were also involved in constant turning of rice. The higher women engagement in sun drying of rice is attributed to women's availability at home to undertake the activity than men who usually engage in non-farm or leisure activities.

This finding however is contrary to Lusiba et. al., (2017) assertion that, assigning key home based activities to women who are already overburdened with domestic chores compromise their inefficiency in performing activities such as adequate drying which is critical for reduction of post-harvest losses. When the rice is dry, it is winnowed before storage. Winnowing is the process of cleaning up the rice grain, i.e. removing the chaff and other foreign matter before consumption, sale or storage. Traditionally, this was an exclusive activity for women who used the winnowing basket. Winnowing is women dominated activity as supported by this finding $(87.5 \%)$. Winnowing precedes storage or marketing. These two activities were performed by women.

From the above finding, it implies that milling, de-stoning and transporting were the major activities carried out by men during rice processing and this could be attributed 
Creative Commons User License: CC BY-NC-ND

Abstracted by: EBSCOhost, Electronic Journals Service (EJS), Google Scholar, Journal Seek, Scientific Commons,

Food and Agricultural Organization (FAO), CABI and Scopus

http://eoi.citefactor.org/10.11226/v24i3
Journal of Agricultural Extension

Vol. 24 (3) July, 2020

ISSN(e): 24086851; ISSN(Print); 1119944X

http://journal.aesonnigeria.org

http://www.ajol.info/index.php/iae

Email: editorinchief@aesonnigeria.org

to the involvement of milling of rice with heavy machines which women might not be able to handle. Threshing, bagging, winnowing, sun drying, soaking, parboiling, packaging, storing and marketing were the major activities performed by women in rice processing as a result of the time involved in processing. This result is in agreement with the finding of Addison, et al., (2016); that women are responsible for drying and winnowing, and storage but contrary to the finding of Achandia, Mujawamariyaa, Agboh-Noameshied, Gebremariame, Rahalivavololonaf, and Rodenburgg (2018) that post-harvest activities (threshing, drying, and milling) and marketing activities In Tanzania are mostly done by men.

Table 2: Distribution of labour in rice production and processing

\begin{tabular}{|c|c|c|c|}
\hline Activities & Men & Women & Children \\
\hline \multicolumn{4}{|l|}{ Rice production activities } \\
\hline Clearing of rice farmland & 90.0 & 0.0 & 10.0 \\
\hline De-stumping of rice farm & 98.3 & 1.7 & 0.0 \\
\hline Tilling of land & 98.3 & 1.7 & 0.0 \\
\hline Planting of rice & 38.3 & 52.5 & 9.2 \\
\hline Weeding of rice farm & 47.5 & 50.8 & 1.7 \\
\hline Thinning of rice farm & 47.5 & 50.8 & 1.7 \\
\hline Application of fertilizer & 90.0 & 10.0 & 0.0 \\
\hline Bird scaring in rice farm & 9.2 & 69.1 & 21.7 \\
\hline Harvesting of rice & 20.0 & 74.2 & 5.8 \\
\hline $\begin{array}{l}\text { Heaping/packaging of harvested } \\
\text { rice }\end{array}$ & 20.0 & 74.2 & 5.8 \\
\hline \multicolumn{4}{|l|}{ Rice processing activities } \\
\hline Threshing & 4.2 & 84.2 & 11.6 \\
\hline Sun drying & 10.8 & 80.9 & 8.3 \\
\hline Bagging & 7.5 & 75.8 & 16.7 \\
\hline Soaking & 2.5 & 91.7 & 5.8 \\
\hline Winnowing & 2.5 & 87.5 & 10.0 \\
\hline Parboiling & 6.7 & 75.0 & 18.3 \\
\hline Sun drying & 10.0 & 73.3 & 16.7 \\
\hline Bagging & 21.7 & 75.0 & 3.3 \\
\hline Milling & 95.8 & 4.2 & 0.0 \\
\hline De-stoning & 95.8 & 4.2 & 0.0 \\
\hline Packaging & 11.7 & 84.1 & 4.2 \\
\hline Transporting & 91.6 & 4.2 & 4.2 \\
\hline Storing & 19.2 & 80.8 & 0.0 \\
\hline Marketing & 10.0 & 90.0 & 0.0 \\
\hline
\end{tabular}

Figure in parentheses represents percentage 
Creative Commons User License: CC BY-NC-ND

Abstracted by: EBSCOhost, Electronic Journals Service (EJS), Google Scholar, Journal Seek, Scientific Commons,

Food and Agricultural Organization (FAO), CABI and Scopus

http://eoi.citefactor.org/10.11226/v24i3
Journal of Agricultural Extension

Vol. 24 (3) July, 2020

ISSN(e): 24086851; ISSN(Print); 1119944X

http://journal.aesonnigeria.org

http://www.ajol.info/index.php/jae

Email: editorinchief@aesonnigeria.org

\section{Rice Output (2012-2016)}

The average rice produced (in $\mathrm{kg}$ ) by men and women from year 2012-2016 is shown in Table 3. In year 2012, men average rice production was $3868.94 \mathrm{~kg}$ while that of women was $2395.08 \mathrm{~kg}$. There was a reduction in rice produced by women in year 2013 to about $2248.48 \mathrm{~kg}$, while that of men increased to $3927.06 \mathrm{~kg}$.

In year 2014, the production stepped up to $4500 \mathrm{~kg}$ for men and $2990.17 \mathrm{~kg}$ for women. In year 2015, there was an increase in rice production for both men $(5452,50 \mathrm{~kg})$ and women $(5069.49 \mathrm{~kg})$. The same increase was noticed in year 2016 as the average production for men stood at $6587.50 \mathrm{~kg}$ while that of women reduced to 4798 . $667 \mathrm{~kg}$. There was an increase in the production right from 2014 to 2016 as a result of government policies which supported banning of rice importation into the country and in turn encouraged the farmers in cultivating more farm land and planting improved varieties of rice which lead to the increase in production in the years. Men's ability to have higher output than women was due to gender division of labour according to task.

There was significant difference in the quantity of rice produced by men and women in year 2012, 2013. 2014, and 2016, while there was no significant difference in the quantity of rice produced in year 2015 (Table 3). Male respondents had greater output of rice than their female counterpart. The result is in support of Van Tran et al., (2019) that, there is significant difference between the quantity of rice produced by male-headed and female headed household in Vietnam. Male headed households produced 10.3 percent higher annual gross value of rice per hectare than female-headed households. However, the result contradicts the findings of Ojo et. al., (2020) that male farmers in south western Nigeria tend to be less efficient compared to their female counterparts, implying that women are on average more technically efficient than men. Kulyakwave, Shiwei, and Yu (2019) also find out that female-headed household in Tanzania could produce rice yield up to $3720 \mathrm{Kg}$ per ha as compared to less yield accrued by male-headed household. This is because in most rural areas of Tanzania specifically in Mbeya, women are more involved in agriculture activities than men. It is also known that in term of social life women are mostly the decision-maker in the region.

Table 3: Average rice produced (2012-2016) on gender basis

\begin{tabular}{lccc}
\hline Year of production & \multicolumn{2}{c}{$\begin{array}{c}\text { Average quantity of rice } \\
\text { Produced (kg) } \\
\text { Men }\end{array}$} & Women \\
\hline 2012 & 3868.94 & 2395.08 & $3.930^{\star}$ \\
2013 & 3927.06 & 2248.48 & $4.748^{*}$ \\
2014 & 4500.00 & 2990.17 & $3.570^{\star}$ \\
2015 & 5452.50 & 5069.49 & 0.308 \\
2016 & 6587.50 & 4798.66 & $3.098^{*}$ \\
\hline
\end{tabular}

${ }^{*} \mathrm{P} \leq 0.05$ 
Creative Commons User License: CC BY-NC-ND

Abstracted by: EBSCOhost, Electronic Journals Service (EJS), Google Scholar, Journal Seek, Scientific Commons,

Food and Agricultural Organization (FAO), CABI and Scopus
Journal of Agricultural Extension

Vol. 24 (3) July, 2020

ISSN(e): 24086851; ISSN(Print); 1119944X

http://journal.aesonnigeria.org

http://www.ajol.info/index.php/jae

Email: editorinchief@aesonnigeria.org

\section{Conclusion and Recommendation}

Men perform most of the tedious field-based and post-harvest activities namely; clearing, de-stumping, tilling of soil, milling, and destoning. These activities also require more physical energy and working in marshy conditions. Women participate more in less physical energy and the home-based post-harvest activities namely; planting, weeding, harvesting, bird scaring, winnowing, and drying. In designing interventions to address the rice production and processing in major energy require activities (like clearing, tilling, milling), it should be tailored towards men while low energy activities (like planting, harvesting, and marketing) interventions should be tailored towards women in order to enhance high productivity and quality processing.

\section{References}

Achandia, E.L., Mujawamariyaa, G., Agboh-Noameshied, A.R., Gebremariame, S., Rahalivavololonaf, N., Rodenburgg, J. (2018). Women's access to agricultural technologies in rice production and processing hubs: A comparative analysis of Ethiopia, Madagascar and Tanzania. Journal of Rural Studies, 60: 188-198.

Addison, M., Ohene-Yankyera, K., Fredua-Antoh, E. (2016). Gender Role, Input Use and Technical Efficiency among Rice Farmers at Ahafo Ano North District in Ashanti Region of Ghana. Journal of Food Security, 4(2):27-35.

African Development Bank \{AfDB\} (2016). Feed Africa: Strategy for Agricultural Transformation in Africa, 2016-2025, AfDB, Abidjan.

Edeoghon, C.O., lyilade, A.O., Nwachukwu, C.G. (2019). Assessment of Gender Participation in Rice Production in Abakaliki, Nigeria. Journal of Biology, Agriculture and Healthcare, 9(12): 37-42.

Global Africa Information Network (2019). Global Africa Information Network (GAIN) Report. Nigeria Grain and Feed Annual 2019, pp.1-14. Retrieved from: https://apps.fas.usda.gov/newgainapi/api/report/downloadreportbyfilename?filename $=$ Grain\%20and\%20Feed\%20Annual Lagos Nigeria 5-6-2019.pdf

Iwuchukwu, J.C., Udegbunam, I.C. (2017). Productivity and Gender/Intra-Household Roles in Rice Production in Awka North Local Government Area, Anambra State, Nigeria. Journal of Agriculture and Ecology Research International, 11(1): 1-9.

KPMG international (2019). Rice Industry Review, October 2019. Retrieved from: https://www.scribd.com/document/441470572/Nigeria-rice-industry-review

Kulyakwave, P.D., Shiwei, X., \& Yu, W. (2019). Households' characteristics and perceptions of weather variability impact on rice yield: empirical analysis of small scale farmers in Tanzania. Ciência Rural, 49(11): 1-13

Lusiba, G.S., Kibwika, P., and Kyazze, F.B. (2017). Intra-household gender division of labour and decision-making on rice postharvest handling practices: A case of Eastern Uganda. Cogent Social Sciences, 3: 1-14.

Mohammed, U.A., Ibrahim, S., Hayatu, M., and Mohammed, F.A. (2019). Rice (Oryza Sativa L.) Production in Nigeria: Challenges and Prospects. Dutse Journal of Pure and Applied Sciences, 5(2): 29-37.

Mohd Hanafiah, N., Mispan, N.S., Lim, P.E., Baisakh, N., and Cheng, A. (2020). The 21st century agriculture: when rice research draws attention to climate variability and how weedy rice and underutilized grains come in handy, Plants, 9(3), 365.

Monica, A., Kwasi O.Y. and Ernestina, F.A. (2016). Gender Role, Input Use and Technical Efficiency among Rice Farmers at Ahafoano North District in Ashanti Region of Ghana. Journal of Food Security, 4(2): 27-35. 
Creative Commons User License: CC BY-NC-ND

Abstracted by: EBSCOhost, Electronic Journals Service (EJS), Google Scholar, Journal Seek, Scientific Commons,

Food and Agricultural Organization (FAO), CABI and Scopus

http://eoi.citefactor.org/10.11226/v24i3
Journal of Agricultural Extension

Vol. 24 (3) July, 2020

ISSN(e): 24086851; ISSN(Print); 1119944X

http://journal.aesonnigeria.org

http://www.ajol.info/index.php/iae

Email: editorinchief@aesonnigeria.org

National Population Commission (2016). National Population Commission and National Bureau of Statistics Estimates. Population 2006-2016. Retrieved from: https://www.google.com/url?sa=t\&rct=j\&q=\&esrc=s\&source=web\&cd=\&cad=ria\&uact $=8 \&$ ved=2ahUKEwih0 W57NXpAhVq7OAKHaNLAWUQFiAAegQIAhAB\&url=https\% 3A\%2F\%2Fnigerianstat.gov.ng\%2Fdownload\%2F474\&usg=AOvVaw0BYliCMVsVxp Ao4le9xgup

Ojo, T.O., Ogundeji, A.A., Babu, S.C. and Alimi, T. (2020). Estimating financing gaps in rice production in South western Nigeria. Journal of Economic Structures, 9(12) 1-18.

Okunola, A.A., Adekanye, T.A., Adewumi, A.D., and Ashamu, F.F. (2019). Assessment of Rice Processing Operations in Ekiti State, Nigeria. International Journal of Civil Engineering and Technology, 10(2): 2197-2204.

Okunola, A.A., Bamigboye, A.I., Olayanju, A., Osueke, O.C. and Alhassan, A.E. (2018). Development of a rice cleaner cum grader for cottage industry processors in Nigeria. International Journal of Mechanical Engineering and Technology, 9(11): 2339-2351.

Omoare, A.M. and Oyediran, W.O. (2020). Factors Affecting Rice Farming Practices among Farmers in Ogun and Niger States, Nigeria. Journal of Agricultural Extension, 24 (2): 92-103.

Osabuohien, E., Okorie, U. and Osabohien, R. (2018). Rice Production and Processing in Ogun State, Nigeria: Qualitative Insights from Farmers' Association. In Obayelu, E. (Eds). Food Systems Sustainability and Environmental Policies in Modern Economics, Hershey, PA: IGI Global. pp. 188-215. DOI:10.4018/978-1-5225-36314.ch009.

Salami, M.F., Babatunde R.O., Ayinde O.E, and Adeoti E.I. (2017). Determinants of poverty among local rice processors in Kwara state, Nigeria. Trakia Journal of Sciences, 15(4): 386-391.

Subramanian, K.R. (2018) Social and Cultural Expectations and Changing Role of Women. International Journal of Engineering and Management Research, 8(2): 110-117.

United Nations Children Emergency Funds (UNICEF) (2017). Gender equality: glossary of terms and concepts. UNICEF regional office for South Asia, Lainchaur, Lekhnath Marg, Kathmandu, Nepal, November 2017. Retrieved from:

https://www.unicef.org/rosa/media/1761/file/Gender\%20glossary\%20of\%20terms\%2 0and\%20concepts\%20.pdf

Van Tran, T.K., Elahi, E., Zhang, L., Bui, V.H., Pham, Q.T., Tran, T.D., Ta, T.L. and Hassan, M. (2019). Gender gap in rice productivity: evidence from Vietnam", International Journal of Social Economics, 46(2): 241-251. 